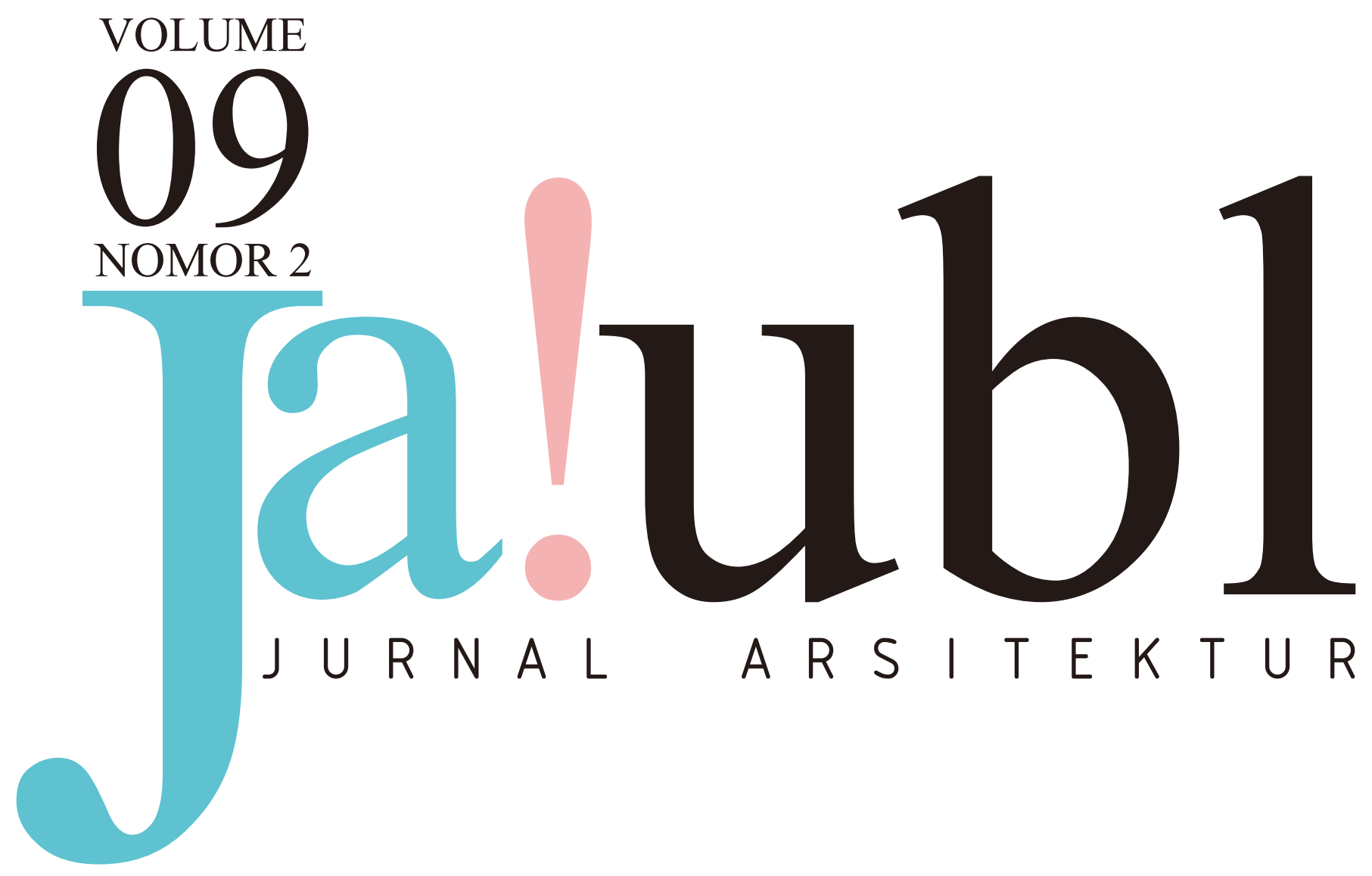


JA!UBL - Jurnal Arsitektur

Terbit dua kali setahun pada bulan Januari dan Juli. Diterbitkan oleh Program Studi Arsitektur Fakultas Teknik Universitas Bandar Lampung. JA!UBL merupakan media pendokumentasian, sharing, dan publikasi karya ilmiah yang berisi karya-karya riset ilmiah mengenai bidang ilmu perancangan arsitektur dan bidang ilmu lain yang sangat erat kaitannya seperti perencanaan kota dan daerah, desain interior, perancangan lansekap, dan sebagainya.

ISSN: 2087-2739

\section{PELINDUNG}

Dr. Ir.H.M.Yusuf Barusman, M.B.A. (Universitas Bandar Lampung)

\section{PENASEHAT}

Dr. Ir. Hery Riyanto, M.T. (Universitas Bandar Lampung)

PENANGGUNG JAWAB

Ir. Tjetjeng Sofjan S., M.M., M.T. (Universitas Bandar Lampung)

\section{PIMPINAN REDAKSI}

Dr.Eng. Haris Murwadi, S.T., M.T.

\section{REDAKSI PELAKSANA}

Shofia Islamia Ishar, S.T., M.T.

Dadang Hartabela, S.T., M.T.

Ai Siti Munawaroh, S.Pd., M.I.L.

Indyah Kumoro Wardani, S.T., IAI

\section{DEWAN REDAKSI}

Prof. Dr. Julaihi Wahid (Universitas Sains Malaysia)

Prof. Dr. Ir. H. Slamet Tri Sutomo, M.S (Universitas Hasanuddin)

Prof. Ir. Totok Rusmanto, M.Eng. (Universitas Diponegoro)

Prof. Dr. Ing. Ir Gagoek Hardiman. (Universitas Diponegoro)

Dr.Eng. Fritz Akhmad Nuzir, S.T., M.A.(L.A.) (Universitas Bandar Lampung)

David Hutama, ST., M.Eng (Universitas Pelita Harapan)

\section{MITRA BESTARI}

Dr. Ir. Budi Prayitno, M.Eng. (Universitas Gajah Mada)

Dr. Eng. Ir. Ahmad Sarwadi, M.Eng (Universitas Gajah Mada)

Prof. Dr. T. Yoyok Wahyu Subroto, M.Eng. Ph. D. (Universitas Gajah Mada)

Dr.Eng. Fritz Akhmad Nuzir, S.T., M.A. (L.A.) (Universitas Bandar Lampung)

Prof. Ir. Liliany Sigit Arifin, M.Sc., Ph. D (Universitas Petra)

Dr. Budi Faisal (Institut Teknologi Bandung)

Dr.Eng. Agus Hariyadi, S.T., M.Sc. (Universitas Gajah Mada)

\section{TIM GRAFIS DESAIN}

Satrio Agung Perwira

B. Chrysvania Artemisia

\section{ALAMAT REDAKSI}

Program Studi Arsitektur Fakultas Teknik Universitas Bandar Lampung

Jalan Zainal Abidin Pagar Alam Nomor. 26 Labuhanratu, Bandarlampung, 35142

Telp. $\quad:$ :0721-773847

E-mail : : editor.j@ubl.ac.id

Homepage : ubl.ac.id 


\section{Daftar Isi Artikel}

01-06 Analisis Penerapan Art Deco pada Rumah di Bandung Periode Perang Dunia I-II Studi Kasus: Tiga Villa dan Perumahan Dosen UPI FADILASARI, Dewi

07-12 Tipologi Bentuk Atap pada Arsitektur Jawa ROOSANDRIANTINI, Josephine; SANTOSO, Angelina Novemita; AMBARWATI, Catherina Novita

13-18 Identifikasi Respon Pengunjung mengenai Keberadaan Desa Wisata Taman Purbakala Pugungraharjo Lampung HARTABELA, Dadang; MASITO, Yuni

19-26 Fenomena Terbentuknya Ruang Spatio-Temporal di Kawasan Stadion Pahoman Bandarlampung WIBAWA, M. Shubhi Yuda

27-32 Identifikasi Area Berpotensi Macet di Kawasan Pendidikan Jl. Z.A. Pagar Alam Bandarlampung PERWIRA, Satrio Agung; MURWADI, Haris; MUNAWAROH, Ai Siti; ISHAR, Shofia Islamia

33-40 Manfaat Ruang Terbuka dan Hubungannya dengan Kegiatan Interaksi Sosial Studi Kasus: Perumahan Nusa Tamalanrea Indah Makassar NURHIJRAH; WIKANTARIA, Ria 


\title{
Fenomena Terbentuknya Ruang Spatio-Temporal di Kawasan Stadion Pahoman Bandarlampung
}

\author{
M. Shubhi Yuda Wibawa ${ }^{1 *}$ \\ ${ }^{1}$ Program Studi Arsitektur, Fakultas Teknik, Universitas Lampung \\ *Penulis Korespondensi: shubhi.yuda@eng.unila.ac.id
}

\begin{abstract}
Abstrak:
Aktivitas masyarakat Kota Bandarlampung yang semakin variatif membentuk hadirnya ruang-ruang publik yang tidak terencana. Ruang publik yang terbentuk hadir pada waktu-waktu tertentu. Dalam hal ini, ruang dan waktu mempunyai keterikatan yang kuat dalam kehidupan masyarakat perkotaan dan kebutuhan akan ruang publik. Dimensi waktu dalam konteks perancangan urban diistilahkan dengan "temporal", sedangkan ruang yang dapat berfungsi mewadahi transformasi aktivitas sesuai dengan transformasi waktu disebut ruang "spatio-temporal". Ruang spatio-temporal ini terlihat hadir di Kawasan Stadion Pahoman, Bandarlampung di mana kawasan ini mempunyai fungsi yang beragam sesuai dengan pergantian waktunya. Dengan menggunakan metoda fenomenologi, penelitian ini akan menganalisis ruang dan aktivitas apa saja yang terbentuk di kawasan Stadion Pahoman, dari pagi hingga malam dan dari Senin sampai Minggu. Hasil dari riset ini dapat digunakan sebagai acuan untuk mengembangkan kawasan Stadion Pahoman di masa mendatang.
\end{abstract}

Kata kunci: aktivitas masyarakat kota Bandarlampung, ruang spatio-temporal

\section{Latar Belakang}

Apresiasi masyarakat terhadap keberadaan kawasan Stadion Pahoman membuat tempat ini memiliki citra sebagai ruang kota yang selalu hidup. Apresiasi tersebut dapat terlihat sejak subuh di mana kawasan Stadion Pahoman dijadikan tempat untuk masyarakat melakukan olah raga dan mencari sarapan. Ketika siang hari tempat ini dipenuhi oleh pedagang kaki lima, sore hari dijadikan tempat untuk berkomunitas dan malam hari dijadikan tempat nongkrong pemuda-pemudi. Pada hari sabtu dan minggu tempat ini menjadi sentra olah-raga, masyarakat berkumpul untuk senam jantung sehat, jogging, bersepeda, dan lain sebagainya. Sedangkan pada hari libur tempat ini dijadikan tempat untuk menyelenggarakan acara/ event.

Apresiasi tersebut merupakan suatu fenomena yang sedang populer seiring dengan berkembangnya kebutuhan akan gaya hidup. Fenomena tersebut juga membentuk kawasan sekitar Stadion Pahoman tumbuh menjadi ruang publik yang tidak lagi hanya diapresiasi sebagai tempat untuk berolah raga dan menyelenggarakan kegiatan yang berhubungan dengan olah raga saja, namun menjadi tempat yang mempunyai sifat temporal ${ }^{1}$. Aktivitas yang semula hanya terjadi pada pagi hari berkembang sampai malam hari. Ruang yang terbentuk juga meluas, dari halaman depan stadion dan kolam renang ke area parkir stadion.

Fenomena tersebut akan diangkat ke dalam penelitian ini dengan berfokus kepada ragam aktivitas yang terjadi dan ruang yang terbentuk secara temporal (spatio-temporal). Penelitian ini akan dilakukan dengan cara mengamati aktivitas pengunjung Stadion Pahoman dan transformasinya sesuai dengan perubahan waktu, dari pagi sampai malam baik pada hari kerja maupun pada hari libur. Dengan demikian titik-titik terbentuknya ruang spatio-temporal akan ditemukan dan dapat menjadi potensi untuk rencana pengembangan di masa mendatang.

Berdasarkan latar belakang di atas, maka permasalahan yang akan dikaji pada penelitian ini adalah:

1. Ragam aktivitas yang terjadi pada kawasan Stadion Pahoman sesuai dengan perubahan waktu

2. Ragam fasilitas yang tersedia untuk mendukung keberlangsungan aktivitas tersebut

Adapun tujuan dari penelitian ini adalah:

1. Memperoleh data tentang aktivitas yang terjadi pada kawasan Stadion Pahoman sesuai dengan perubahan waktu

2. Memperoleh data tentang Ragam fasilitas yang tersedia untuk mendukung keberlangsungan aktivitas tersebut

3. Memperoleh titik-titik terbentuknya ruang spatio-temporal pada kawasan Stadion Pahoman.

Area yang diamati pada penelitian ini adalah seluruh halaman Stadion Pahoman meliputi halaman depan, area parkir, halaman gedung Anggar, halaman sisi utara dan halaman depan kolam renang. 


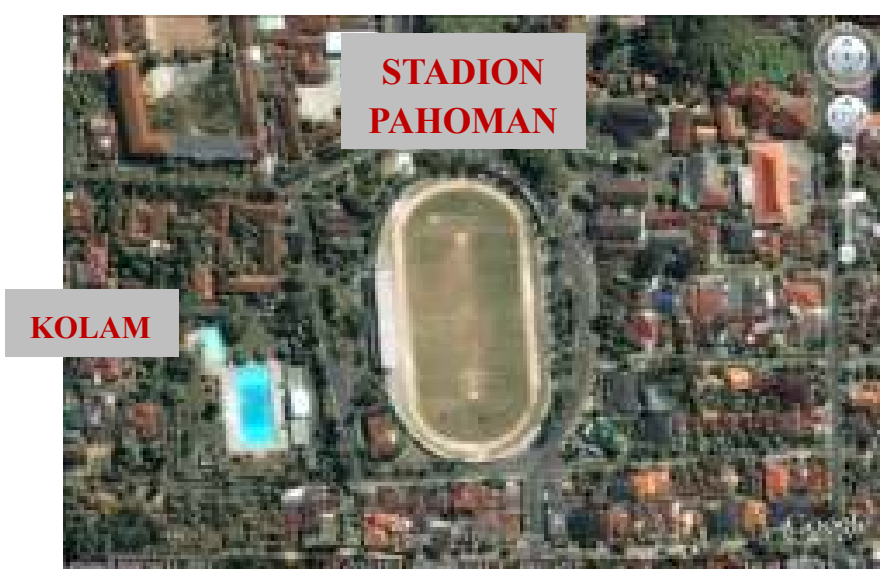

Gambar 1. Stadion dan Kolam Renang Pahoman

\section{Teori Ruang Spatio-Temporal}

Menurut Mathew Carmona (2003) dalam buku Public Places- Urban Places, "temporal" merupakan wujud dimensi ke- 4 dari konsep ruang dalam konteks teori urban. Suatu tempat akan selalu terkait dengan waktu sehingga pada perkembangannya, tempat memiliki identitas waktunya masing-masing. Tempat juga akan memiliki makna yang kuat seiring dengan waktu berlalu.

Ruang spatio-temporal terhubung dengan siklus waktu dan siklus aktivitas manusia berdasarkan waktu tersebut. Siklus aktivitas manusia akan selalu membutuhkan fasilitas dan ruang. Manusia merasakan bagian waktu dalam lingkungan kota melalui dua cara. Cara yang pertama adalah melalui pengulangan ritmis; detakan jantung, bernafas, tidur, bangun, lapar, siklus bulan dan matahari. Cara yang kedua adalah melalui perubahan progresif dan perubahan yang tak dapat diubah seperti, pertumbuhan dan pembusukan yang bersifat tidak kambuh namun berganti. Waktu dan ruang sangat berhubungan erat sehingga ruang dan waktu menjadi kerangka yang sangat kuat untuk manusia membentuk pengalamannya.

Kunci keberhasilan suatu ruang spatio-temporal adalah manajemen waktu. Manajemen waktu untuk menanggapi dan merespon perubahan aktivitas dengan memberi alternatif fungsi ruang. Ruang- ruang spatiotemporal pada saat ini berkembang menjadi ruang yang sengaja dirancang dengan memiliki fungsi ganda. Dirancang berdasarkan pergerakan aktivitas dan kebutuhan manusia dari siklus kehidupannya. Dalam konteks ruang urban, sebuah ruang spatio-temporal memiliki tujuan memperkuat keterikatan sosial dengan cara mengumpulkan banyak dan memberikan mereka sesuatu yang sama.

\section{Metode}

Penelitian ini menggunakan metoda fenomenologi yaitu suatu metoda yang pada dasarnya bersifat a priori sehingga tidak diawali dan didasari oleh teori tertentu. Penelitian fenomonologi berangkat dari filsafat tentang apa yang diteliti dan bagaimana menelitinya. Penelitian ini akan dilakukan dengan cara mengamati aktivitas pengunjung Stadion Pahoman dan transformasinya sesuai dengan perubahan waktu.

\subsection{Pengumpulan Data}

Meliputi kegiatan sebagai berikut:

1. Pengumpulan Data Sekunder

Data yang diperlukan dalam kegiatan ini adalah studi literatur terhadap teori mengenai ruang spatio-temporal dalam teori rancang kota.

2. Pengumpulan Data Primer

Data-data primer meliputi observasi lapangan/pengamatan langsung. Output observasi ini berupa:

1. Data pengunjung berupa jumlah, keperluan, jenis kelamin dan usia.

2. Data fasilitas yang tersedia dan rentang waktunya

\subsection{Sampling}

Sampling meliputi penentuan zona penelitian dan penentuan waktu survei. Zona penelitian merupakan area yang paling sering digunakan untuk beraktivitas di luar aktivitas yang berlangsung di dalam stadion dan kolam renang. Zona penelitian juga merupakan area terjadinya aktivitas yang membentuk siklus waktu, dari pagi hingga malam hari dan terjadi berulang sepanjang tahun. Oleh karena itu, pemilihan waktu penelitian juga disesuaikan dengan siklus waktu yang terbentuk yaitu dari pagi sampai malam hari. Berikut adalah batasan zona penelitan dan batasan waktu pengamatan. 
1. Zona penelitian

Zona penelitian dibagi ke dalam 5 zona yaitu:
a. Zona 1 : halaman depan stadion
b. Zona $2:$ area parkir stadion
c. Zona 3 : halaman gedung anggar
d. Zona 4 : halaman depan kolam renang
e. Zona 5 : halaman sisi utara

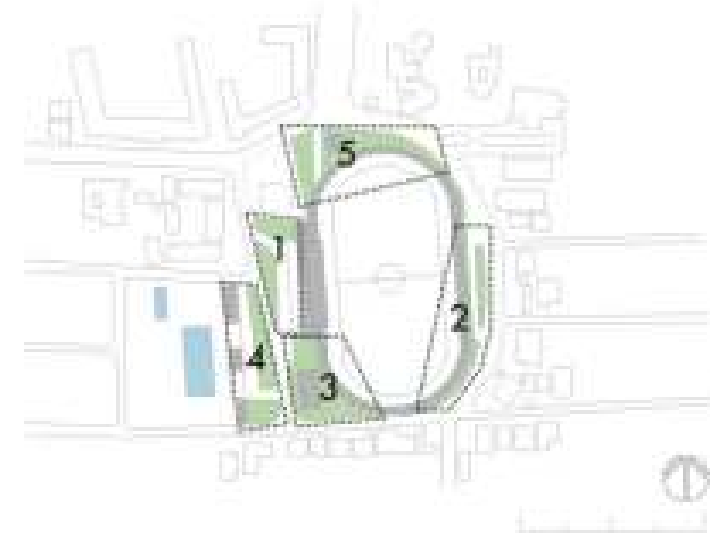

Gambar 2. Peta zona penelitian

2. Waktu pengamatan

Senin - kamis

a. Pagi hari : pukul $07.00-08.00 \mathrm{WIB}$

b. Siang hari : pukul $12.00-13.00 \mathrm{WIB}$

c. Malam hari : pukul $19.00-20.00 \mathrm{WIB}$

Jumat - Sabtu

a. Pagi hari : pukul $07.00-08.00 \mathrm{WIB}$

b. Siang hari : pukul $12.00-13.00 \mathrm{WIB}$

c. Malam hari : pukul $19.00-20.00$ WIB

Minggu

a. Pagi hari : pukul $06.00-08.00 \mathrm{WIB}$

b. Siang hari : pukul $12.00-13.00 \mathrm{WIB}$

c. Malam hari : pukul $19.00-20.00 \mathrm{WIB}$

\section{Kondisi Eksisting}

Kawasan Stadion Pahoman terletak di Kelurahan Pahoman, Kota Bandarlampung. Kawasan Stadion Pahoman merupakan salah satu sentra aktivitas olah raga dan kuliner bagi masyarakat Kota Bandarlampung. Posisinya yang berada di tengah kota menjadikan kawasan ini mudah diakses.

Kawasan ini memiliki dua fasilitas olah raga yang posisinya saling berdampingan yaitu stadion olah raga dan kolam renang. Keberadaan kedua fasilitas ini merupakan pemicu terbentuknya aktivitas dan fasilitas baru baik yang sengaja dirancang sebagai fasilitas pendukung maupun yang muncul dengan sendirinya.

Aktivitas yang terbentuk selain aktivitas olah raga di dalam stadion dan kolam renang sangat variatif, mulai dari aktivitas olah raga, kuliner, jual beli sampai ke aktivitas nongkrong yang dilakukan oleh sekumpulan pemuda. Munculnya aktivitas ini disebabkan tersedianya ruang terbuka yang berada di sekitar stadion dan kolam renang. Ruang terbuka ini berupa halaman stadion, halaman parkir dan taman yang dimiliki stadion dan kolam renang.

Pada kondisi eksisting ini, akan dikaji aktivitas yang terjadi dan fasilitas yang tersedia pada zona-zona penelitian berdasarkan siklus pergantian waktu. Terdapat lima zona penelitian dan tiga kelompok waktu pengamatan. Masing-masing zona akan dikaji berdasarkan kelompok waktu yang sudah ditentukan yaitu berdasarkan jam dan hari (Senin sampai Jumat, Sabtu dan Minggu).

\subsection{Aktivitas Hari Senin, Selasa, Rabu dan Kamis}

Pada pagi hari di hari senin sampai kamis, zona satu digunakan untuk aktivitas memarkir kendaraan. Aktivitas belum variatif karena sebagian besar pengguna zona 1 merupakan pengunjung yang beraktivitas di dalam stadion. fasilitas yang tersedia berupa ruang terbuka dengan perkerasan, ruang terbuka hijau dan trotoar. 

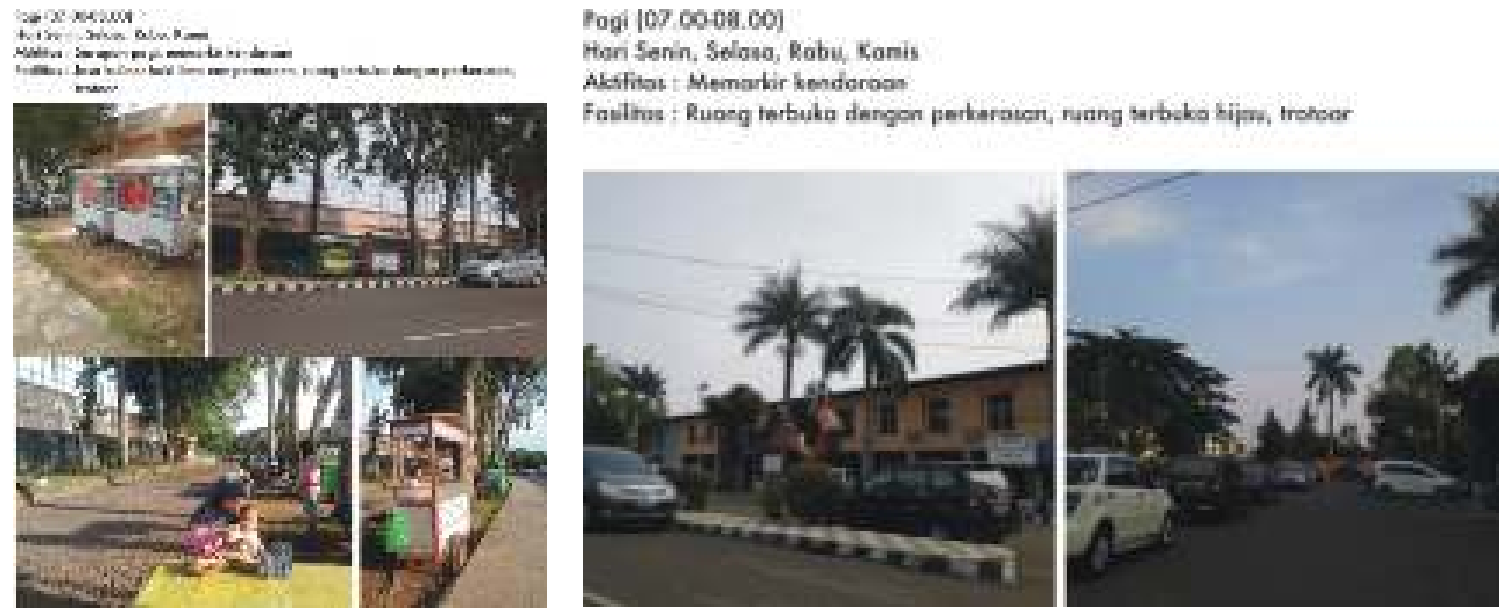

Gambar 3. Aktivitas pada hari Senin- Kamis

Pada siang hari aktivitas dan fasilitas mulai beragam. Aktivitas yang berlangsung adalah, aktivitas jual-beli dan memarkir kendaraan. Nuansa berbelanja makanan atau dikenal dengan jajan sangat terasa pada siang hari karena jumlah jasa pedagang kaki lima yang bertambah banyak. Jumlah fasilitas pedagang kaki lima pada siang hari berkisar antara empat sampai lima unit.

Pada malam hari jenis aktivitas mulai berubah menjadi lebih intim. Pada zona ini terdapat aktivitas makan malam dengan penerangan yang seadanya. Aktivitas makan malam ini difasilitasi oleh satu jasa pedagang kaki lima yang menjual nasi dan mi goreng.

\subsection{Aktivitas Hari Jumat dan Sabtu}

Pada hari Jumat dan Sabtu aktivitas di zona 1 ramai dengan pengunjung yang berolah raga pagi. Pengunjung yang berolah raga di dalam stadion memarkirkan kendaraannya pada zona ini tepatnya pada halaman depan stadion, sedangkan pengunjung yang berolah raga di luar stadion melewati zona ini dengan berlari santai, berjalan kaki dan beristirahat sambil duduk duduk di trotoar.
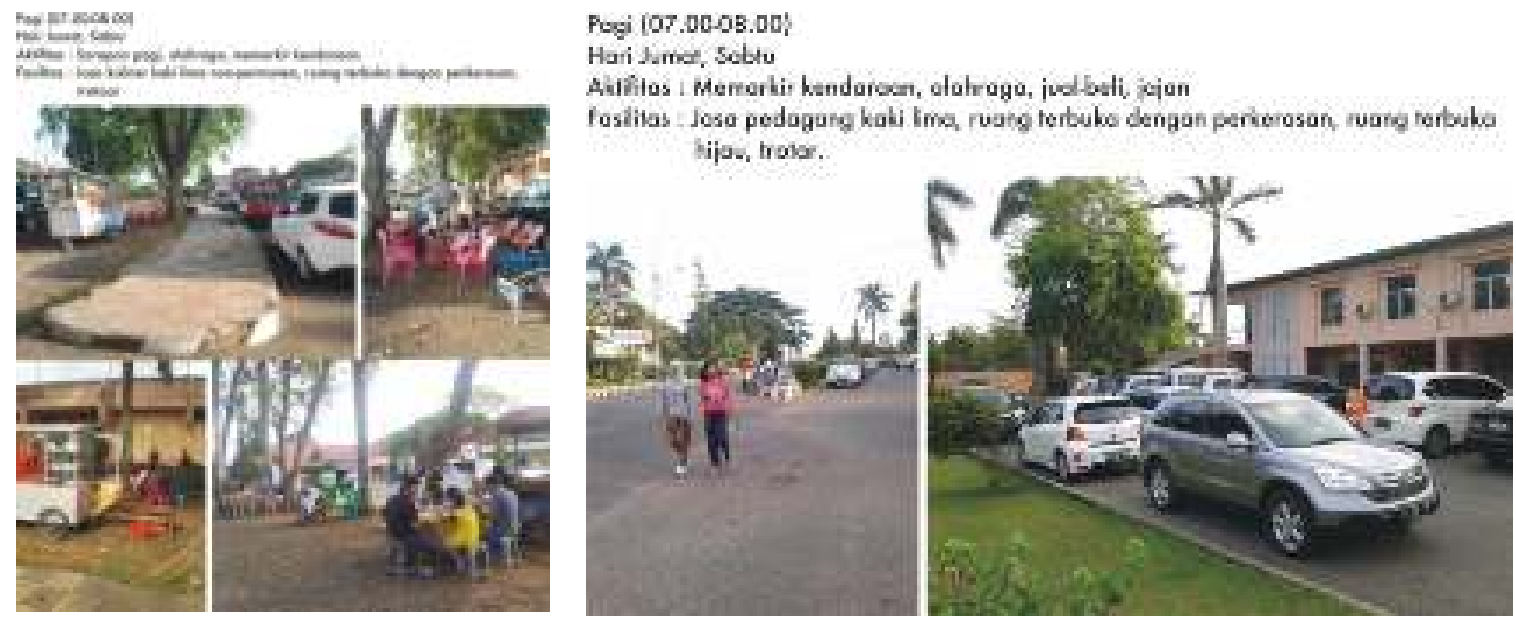

Gambar 4. Zona 1 Aktivitas pada hari Jumat dan Sabtu

Kondisi siang hari pada hari Jumat dan Sabtu pada zona ini terlihat berbeda dengan hari-hari sebelumnya yaitu senin sampai Kamis. Pengunjung yang datang lebih banyak. Pada hari Jumat, jumlah kendaraan yang parkir jauh lebih banyak dikarenakan ada aktivitas Sholat Jumat di zona 2 yang memberikan dampak juga di zona ini. Sedangkan pada hari Sabtu yang merupakan akhir pekan, jumlah pengunjung bertambah karena pada hari ini pengunjung yang merupakan anak sekolah, mahasiswa dan pegawai kantoran memiliki waktu luang untuk mengunjungi zona ini untuk sekadar berwisata kuliner dan nongkrong.

Pada malam hari di hari Jumat dan Sabtu, aktivitas yang terjadi lebih ramai dibandingkan dengan hari-hari sebelumnya. Terdapat remaja-remaja yang sedang bercengkrama dan menghabiskan waktu sambil menikmati makanan yang dibeli di pedagang kaki lima. 


\subsection{Aktivitas Hari Minggu}

Pada hari minggu pagi, zona ini sangat ramai dengan pengunjung yang melakukan aktivitas olah raga. Jasa pedagang kaki lima juga bertambah dan semakin bervariasi. Terdapat beberapa jasa kaki lima dadakan yang hanya berjualan pada hari ini.
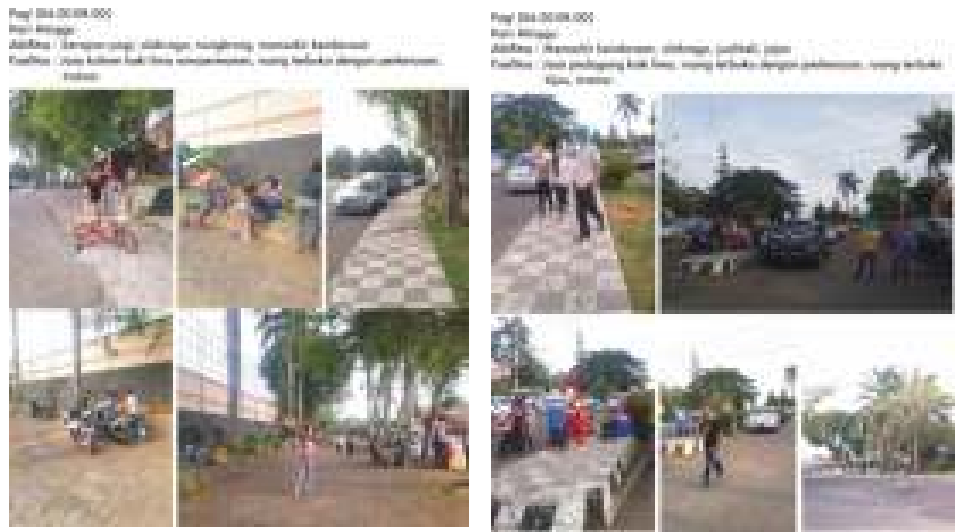

Gambar 5. Aktivitas pada hari Minggu.

Pada siang hari kuantitas pengunjung dan pedagang kaki lima dadakan mulai berkurang. Aktivitas olah raga juga sudah tidak lagi terlihat di zona ini namun terdapat aktivitas nongkrong bagi sebagian pengunjung yang ingin menghabiskan waktunya dengan berkumpul bersama teman maupun kolega.

Pada Minggu malam, kepadatan aktivitas di zona ini meningkat kembali. Dengan suasana intim, banyak pasangan yang menghabiskan waktu sambil menikmati makan malam yang dibeli di pedagang kaki lima. Ada juga pasangan yang sekadar memarkirkan motornya dan duduk-duduk menghabiskan waktu bersama pasangan di atas motor sambil menikmati nuansa romantis malam Minggu.

\section{Hasil}

Pengamatan yang dilakukan terhadap lima zona di kawasan Stadion Pahoman menghasilkan pola pergerakan, sebaran aktivitas dan fasilitas yang berbeda pada masing-masing zona yang diamati berdasarkan siklus waktu pengamatan.

\subsection{Zona 1}

Seborac okfivios das konilios podo zono 1 . selono I mingav (Senis Mingou)

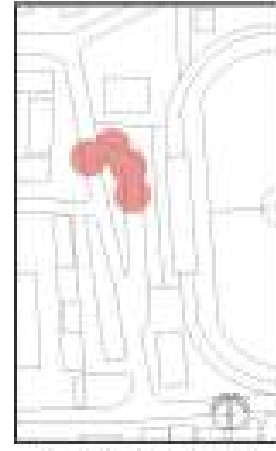

Pagi $(07.0008 .00\}$

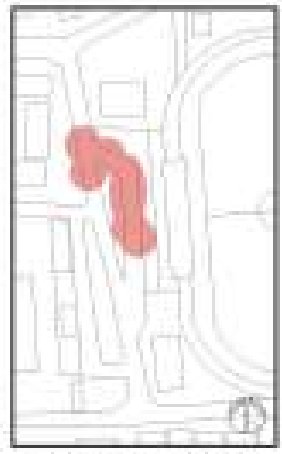

Siana $(12.00-13.00)$

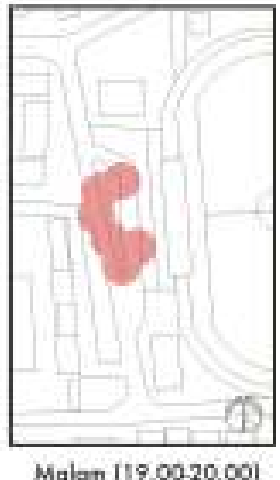

Malan [19.00-20.00]

Gambar 6. Analisis Zona 1

Pola pergerakan dan sebaran aktivitas pada zona 1 terkonsentrasi pada sisi utara di pagi hari. Hal ini dikarenakan banyaknya kendaraan pengantar siswa-siswi sekolah serta pengunjung yang berolahraga di dalam stadion. Pintu stadion yang dibuka pada sisi sebelah utara zona ini mengakibatkan banyak pengunjung yang memarkir kendaraan di area tersebut. Pada siang hari sebaran aktivitas semakin melebar ke sisi selatan zona sebagai imbas banyaknya kendaraan yang parkir. Meningkatnya jumlah kendaraan dikarenakan adanya kendaraan jemputan siswa-siswi sekolah serta pengunjung yang hendak jajan dan makan siang di kawasan ini. Jumlah dan variasi jasa kuliner kaki lima juga bertambah banyak pada siang hari di zona ini. Sedangkan pada malam hari pergerakan aktivitas lebih terkonsentrasi ke sisi tengah dari zona 1, karena area ini yang memiliki fasilitas penerangan paling baik. Aktivitas yang dominan hadir pada zona ini adalah memarkir kendaraan dan berkumpul. 


\subsection{Zona 2}

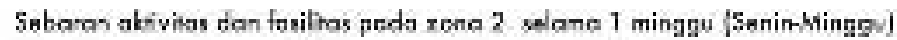

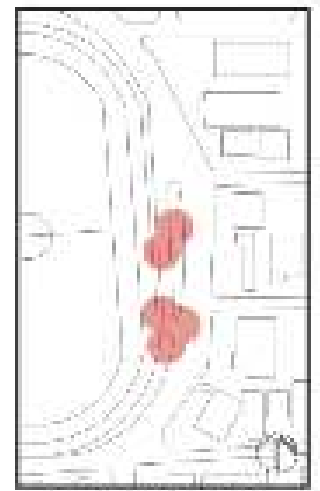

$\operatorname{Pog} 107.0008 .001$

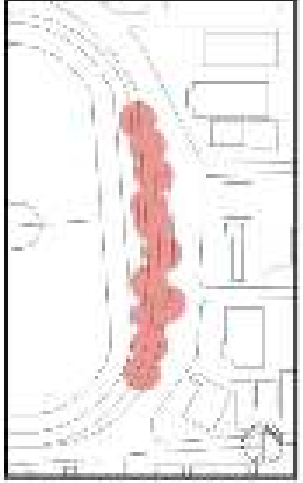

Siong $[12.00-13.00)$

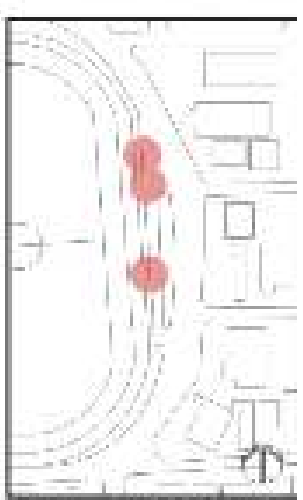

Molem $(19,00-20.00)$

Gambar 7. Analisis Zona 2

Pada zona 2 pola pergerakan aktivitas dan fasilitas telihat jelas perbedaannya pada siklus pergantian waktu. Pada pagi hari aktivitas yang dominan adalah sarapan pagi dimana banyak jasa kuliner kaki lima yang terkonsentrasi di sisi tengah dari zona ini. Jumlah dan variasi jasa kaki lima meningkat seiring pergantian waktu menuju siang, dimana fasilitas tersebar di sepanjang area zona 2 ini. Adanya sebaran fasilitas kaki lima berdampak pada sebaran aktivitas yang terjadi pada zona ini di siang hari. Jumlah aktivitas khususnya parkir kendaraan di zona 2 meningkat tajam pada hari Jumat sebagai imbas masyarakat yang melaksanakan shalat Jumat di Masjid Al Muslimin. Namun pola pergerakan aktivitas dan jumlah fasilitas kaki lima menurun drastis pada malam hari, dimana hanya terdapat 2 jasa kaki lima pada zona ini yang terkonsentrasi di sisi utara. Minimnya penerangan pada malam hari berdampak pada menurunnya jumlah aktivitas dan fasilitas di zona ini. Pada zona 2 ini jasa kuliner kaki lima merupakan fasilitas yang dominan ada sepanjang pergantian siklus waktu. Tidak hanya dominan dari segi jumlah, namun juga ragam jenisnya.

\subsection{Zona 3}

Seboran oktivizas dan fasilias pada zona 3 selama 1 minggu (Senin-Minggu\}

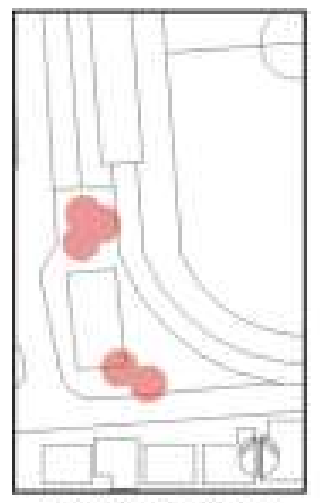

Pagi $(07.00-08.00)$

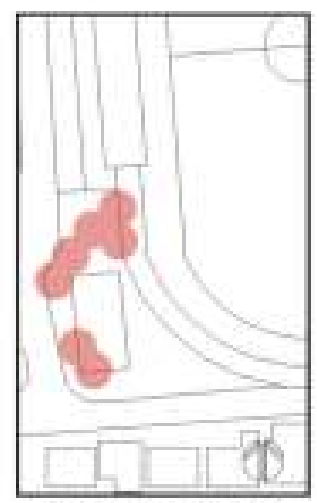

Siang $(12,00-13,00)$

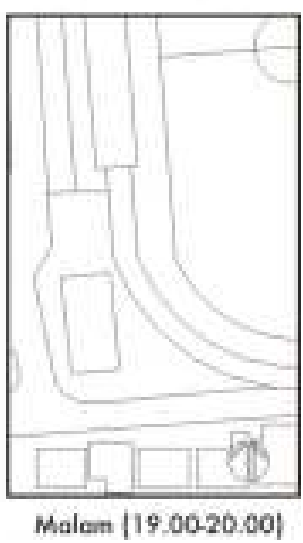

Malem $(19.00-20.00)$

Gambar 8. Analisis Zona 3

Pada Zona 3 pola pergerakan aktivitas dan fasilitas terkonsentrasi pada waktu pagi hari dan siang hari. Pada waktu pagi hari aktivitas yang dominan adalah sarapan pagi. Terdapat jasa kuliner kaki lima di sisi utara zona ini yang menjadi fasilitas utama. Sisi selatan zona 3 menjadi area olahraga dan berkumpul pada hari Minggu pagi seiring meningkatnya jumlah pengunjung dan ragam aktivitas. Pada siang hari aktivitas masih didominasi oleh kuliner dengan adanya jasa kaki lima di sisi utara zona ini meski jenisnya berbeda dengan yang ada pada pagi hari. Ruang terbuka hijau yang ada di sisi selatan zona 3 ini biasanya dimanfaatkan sebgai tempat istirahat dan berkumpul pada siang hari. Jasa kaki lima yang menghilang pada malam hari menyebabkan tidak adanya daya tarik pada zona ini di malam hari, selain sebagai tempat singgah segelintir pasangan yang berhenti di sisi selatan zona meskipun ada penerangan yang cukup baik. Adanya bangunan anggar juga tidak termanfaatkan dengan baik, dimana sepanjang pengamatan dilakukan tidak pernah ada aktivitas di dalam bangunan ini. 


\subsection{Zona 4}

Seberan oktivitas den fasilitas poda zane 4 selame 1 minggu (Senie-Minggu)

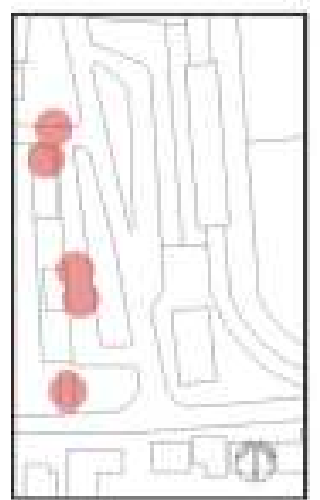

Popi $\{07.0008 .00\}$

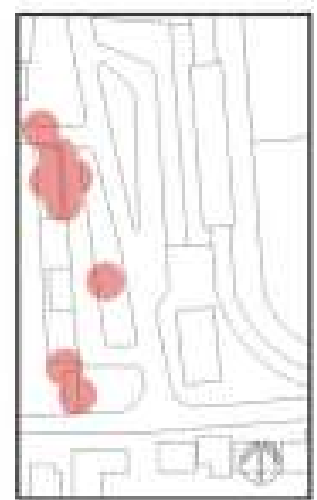

Siong $\{12.00-13.00\}$

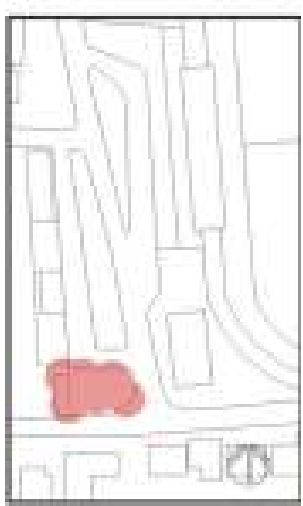

Malam $\{19.0020 .00\}$

Gambar 9. Analisis Zona 4

Zona 4 merupakan area kolam renang Pahoman, dimana tidak banyak pola pergerakan dan aktivitas yang hadir pada pagi hari. Aktivitas didominasi oleh olahraga berupa senam jantung sehat pada Minggu pagi. Selain itu aktivitas yang terekam selama pengamatan pada pagi hari adalah persiapan bagi area kuliner di sisi utara dan selatan zona ini. Pola pergerakan aktivitas dan fasilitas meningkat pada siang hari, terutama di area kuliner pada sisi utara zona. Jasa kuliner kaki lima yang dipusatkan pada sisi utara ini menjadi daya tarik tersendiri bagi pengunjung sehingga meningkatkan densitas pergerakan dan aktivitas.

Menjelang malam hari, tingkat aktivitas bergerak ke sisi selatan zona dimana terdapat jasa kuliner semi permanen dan ruang terbuka hijau. Jumlah pengunjung semakin ramai pada malam hari terutama pada hari-hari libur. Kehadiran mini market waralaba di seberang sisi selatan menjadi daya tarik bagi pengunjung untuk beraktivitas pada zona ini.

\subsection{Zona 5}

Sobaran aktivitus tan faslitan proda xana 5 xaluma 1 minggu |Sarimhinggu|

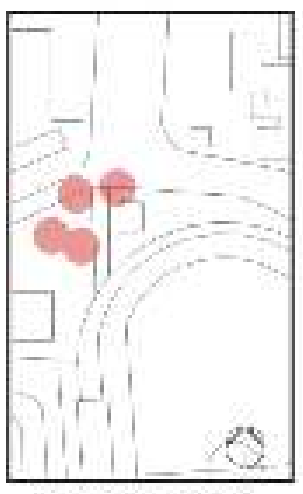

Paqi |07.c003.co|

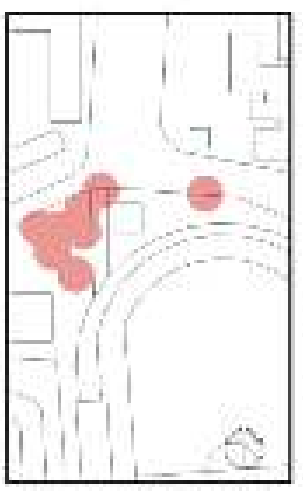

Siana $\{12.02-13.00\}$

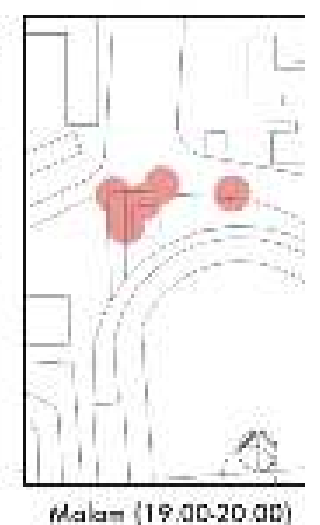

Malan $\{19.00-2000\rangle$

Gambar 10. Analisis Zona 5

Aktivitas dan fasilitas pada zona 5 banyak dipengaruhi oleh adanya sekolah-sekolah di sekitar kawasan stadion, yang mengakibatkan adanya perbedaan signifikan pada pola pergerakan aktivitas dan fasilitas pada saat hari kerja dengan akhir pekan di siklus pergantian waktu. Terlihat pada pola pergerakan dan aktivitas zona 5 di pagi hari saat hari kerja, dimana aktivitas didominasi oleh kendaraan pengantar serta siswa-siswi yang jajan di beberapa jasa kaki lima yang ada. Pada hari minggu pagi zona ini relatif sepi, dan hanya digunakan oleh beberapa pengunjung untuk berkumpul dan berolahraga.

Tingkat kepadatan dan aktivitas meningkat pada siang hari di hari kerja, dimana jumlah dan ragam jasa kaki lima meningkat dibandingkan pagi hari. Hal ini dikarenakan berakhirnya jam sekolah bagi siswa-siswi sehingga zona ini menjadi sangat ramai. Namun keadaan berbalik di hari minggu siang, dimana hampir tidak ada aktivitas berarti di zona ini. Pola pergerakan aktivitas dan fasilitas di zona ini hampir seragam di malam hari, baik disaat hari kerja maupun akhir pekan. Aktivitas diisi oleh pengunjung yang makan malam dan berkumpul di area ini. 


\section{Kesimpulan}

Aktivitas dan fasilitas yang hadir pada kawasan stadion Pahoman pada dasarnya terbentuk dari kebutuhan masyarakat akan ruang untuk bersosialisasi dan berkontemplasi dalam skala urban. Kondisi masyarakat yang beragam menghasilkan variasi aktivitas dan keinginan yang berbeda dalam rentang waktu tertentu. Hal ini yang kemudian mendasari terbentuknya ruang spatio temporal pada kawasan stadion Pahoman. Pola pergerakan aktivitas dan fasilitas yang terjadi pada kawasan ini memperlihatkan bagaimana setiap zona memiliki identitas pada waktunya masing-masing.

1. Zona 1 sebagai halaman depan Stadion Pahoman banyak dimanfaatkan sebagai area parkir dalam siklus waktunya, meskipun ada aktivitas dan fasilitas lain yang muncul pada rentang waktu tertentu.

2. Aktivitas yang berkaitan dengan kulinari merupakan identitas yang muncul pada zona 2. Ditandai dengan ragam jasa kuliner kaki lima yang dominan hadir sepanjang siklus waktunya.

3. Tidak banyak variasi pola pergerakan aktivitas dan fasilitas pada zona 3. Ruang yang ada tidak mampu menjadi katalis aktivitas, dimana gedung Anggar yang menjadi fasilitas utama zona ini justru hampir tidak pernah terlihat ada aktivitas di dalamnya.

4. Adanya bangunan semi permanen sebagai area kuliner yang terdesain dan dikelola dengan baik menjadikan zona 4 sebagai daya tarik utama kawasan ini pada siang hari. Ragam jenis jasa kuliner yang ada memberi banyak pilihan bagi pengunjung yang beragam pula. Zona 4 juga memiliki transisi pergerakan densitas yang jelas antara siklus waktu siang dan malam meskipun aktivitasnya relatif sama.

5. Zona 5 memberikan pengalaman yang jelas bagaimana ruang spatio temporal terbentuk dari siklus aktivitas dan siklus waktu. Pola pergerakan aktivitas dan fasilitas pada zona ini sangat dipengaruhi oleh keberadaan sekolah-sekolah yang ada pada kawasan stadion Pahoman.

6. Identifikasi aktivitas dan fasilitas pada kawasan stadion Pahoman yang membentuk ruang spatio temporal akan memberi arahan yang jelas bagi pengembangan kawasan secara keseluruhan sehingga memperkuat keterikatan sosial masyarakat dalam konteks urban.

\section{Daftar Pustaka}

Broadbent, G. (1990). Emerging Concepts in Urban Space Design. New York: Van Nostrand Reinhold Company.

Carr, S., Francis, M., Rivlin, L., Stone, A. (1992). Public Space. United States of America: Cambridge University Press.

Carmona, M., Heath, T., Oc, T., Tiesdell, S. (2003). Public Places - Urban Spaces: The Dimensions of Urban Design. Great Britain: Architectural Press.

Dovey, K. (1999). Framing Places, Mediating power in built form. London: Routledge.

Jiang, Shan. Ferreira, Joseph. Gonzales, Marta C. (2012). Discovering urban spatial-temporal structure from human activity patterns. Association for Computing Machinery (ACM)

Krier, R. (1979). Urban Space, London: Academy Editions.

Madanipour, A. (1996). Design of Urban Space, An Inquiry into a Socio-spatial Process. Newcastle: University of Newcastle.

Project for Public Space (PPS). (2001). How to Turn a Place Around: A Handbook for Creating Successful Public Spaces, New York: Project for Public Spaces, Inc.

Trancik, R. (1986). Finding Lost Space. New York: Van Nostrand Reinhold Company.

http://lib.uin-malang.ac.id/thesis/chapter_iii/07110058-labudda-mh.ps 


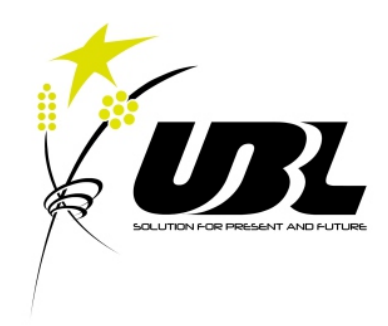

Published:

Program Studi Arsitektur Fakultas Teknik Universitas Bandar Lampung 